\title{
Analysis of Brazilian fashion sectorial brand identity
}

\begin{tabular}{|r|l|}
\hline Journal: & Research Journal of Textile and Apparel \\
\hline Manuscript ID & RJTA-12-2017-0055.R3 \\
\hline Manuscript Type: & Original Manuscripts \\
\hline Keyword: & $\begin{array}{l}\text { Brand Identity, Sectorial brand, Brand partners perceptions, Sectorial } \\
\text { brand management. }\end{array}$ \\
\hline \multicolumn{2}{|l}{} \\
\hline
\end{tabular}

SCHOLARONE ${ }^{m}$

Manuscripts 


\section{Analysis of Brazilian fashion sectorial brand identity}

\section{Introduction}

Interorganizational actions in marketing are developed for different purposes by companies Agostini and Nosella (2017). Organisational alliances in marketing can help companies access new markets, promote internationalisation process (Veilleux et al., 2012) and reduce costs (Agostini and Nosella, 2017). One of the possible types of organisational alliances in marketing is the creation of shared brands between the companies involved (Agostini and Nosella, 2017). In these cases, relationships are developed to generate cooperative marketing activities that act with

9 a unique identity to represent two or more companies, and brand management is governed by an independent entity (Tregear and Gorton, 2009).

Several countries have used shared brands as a strategy to associate a group of companies in 12 an industry with their region of origin (Aichner, 2014). The commitment to using them is 13 because adding information about producer region can increase consumer confidence in product 14 quality (Bruwer and Johnson, 2010). This phenomenon occurs because of country of origin (COO) (Zeugner-Roth and Zabkar, 2015), where many countries are often positively associated with the production of relative products. Because of this, shared brands are developed, so they

17 can link the product to its origin. This is the case, for example, for a Champagne brand, which represents several wineries in the northern region of France (Charters and Spielmann, 2014) or the Café de Colombia brand, which also represents producers in a particular region of Colombia 20 (Barjolle et al., 2017).

Although shared brands are being used around the world, there are discrepancies about their

22 definitions and rules of use, a fact that sometimes hinders understanding and makes comparative 23 studies difficult (Castro and Giraldi, 2015). In Brazilian context, shared brands can be classified 
24 into three types: (i) geographical indications; (ii) collective brands; (iii) sectorial brands (Castro 25 and Giraldi, 2015). Geographical indicators constitute an instrument for a product valuation that 26 are territorially distinguished and recognised for their quality. Moreover, collective brands, on 27 other hand, are awarded to a group of organisations that market the same product and wish to 28 link quality to its associated companies. Products do not have to be produced in an enclosed 29 geographical region and their registration does not require a geographical name, as it does in geographical indications (Castro and Giraldi, 2015). Finally, sectorial brands (third group) are

31 developed by less restricted projects that aim to represent all sector of a country internationally 32 and stimulate its exports (Lourenção and Giraldi, 2017). Any company that is part of the sector can be part of sectorial brand, it does not need to prove a certain mode of production and/or 34 quality of its products (Castro and Giraldi, 2015; Lourenção and Giraldi, 2017).

Sectorial brands can also contribute to helping small companies gain more international visibility when attending events abroad (Tregear and Gorton, 2009). Therefore, it is important 37 that countries develop this type of shared brand, since it is a less restricted option and does not require proof for mode of production as in the case of geographical indications (Castro and 39 Giraldi, 2015).

A few studies have indicated a difficulty in developing the identity of sectorial brands that is 41 suitable for all partners (Lourenção and Giraldi, 2017; Tregear and Gorton, 2009). Iversen and 42 Hem (2008) suggest that, in order to mitigate this challenge, it is necessary, before developing 43 the brand, to identify common attributes that participants wish to communicate and that will be 44 represented by the shared brand.

He and Balmer (2006) outlined that, for efficient management of brand alliance, it is necessary to manage diversity between the partners and their different stakeholders. In the 
47 literature there are already studies that seek to assist the creation and management of this type of sectorial brands. The study by Lourenção and Giraldi (2017), for example, develops a structured model that indicates several elements which must be analysed for the construction of sectorial 50 brands identity. However, no studies have yet established how similar elements should be 51 identified among brand partners, hence a gap in theoretical framework being identified. In order 52 to bridge this gap between theory and practice, the objective of this study is to identify similar 53 characteristics and managerial actions of the sector brand identity elements among the 54 associations that compound the Brasil Fashion System brand. This objective would contribute to 55 form an appropriate brand identity for all partners involved, a topic whose importance has 56 already been highlighted in the literature (Lourenção and Giraldi, 2017; Tregear and Gorton, 57 2009; Iversen and Hem, 2008).

The sector chosen to carry out this study was the Brazilian fashion sector, represented by the Brasil Fashion System sector brand (BFS). The reason for choosing this brand is that it is composed of seven distinct associations. Moreover, it is also possible that there are distinct attributes that the associations would like to be communicated by the brand to represent them

62 abroad, making it difficult to create a unique brand identity. As indicated by Sutter et al., (2014), the Brazilian fashion industry has faced some difficulties while consolidating its identity 64 internationally.

It is intended that with the identification of common brand attributes among Brazilian fashion industry associations, its sector brand identity can be improved and the challenges of 67 brand consolidation and standardisation globally could be tackled effectively, enabling a better brand management overall. So, this is one intended economic and commercial impact of this study. In addition, the study also contributes to the literature, which presents challenges faced by 
sectorial brands (Lourenção, Castro and Giraldi, 2017; Tregear and Gorton, 2009; Iversen and Hen, 2008). However, in a search conducted in the databases of Science Direct and Scopus, empirical studies of the application of possible solutions to these challenges have not yet been found. So, the present study seeks to identify a conceivable resolution to one of the sectorial brand challenges, once it proposes to identify common characteristics among the partner associations for the sectorial brand identity and, by doing this, will contribute to the consolidation and standardisation of its identity abroad, considered as one sectorial brand challenge (Sutter et al., 2014; Lourenção and Giraldi, 2017).

\section{Brand Identity and Image}

The concept of brand image is something that basically represents what consumers think about the brand and the feelings that stand out when they encounter a recall (Roy and Barnerjee, 2008). For Dinnie (2008), the image refers to how a brand is perceived. Additionally, Mindrut et al., (2015) comment that the components of brand identity are a vehicle that leads to the formation of their image. However, in order for the brand image to be created in the consumer's mind in a desired way, it is necessary that brand identity be appropriately promoted (Vásquez, 2007).

Urde and Greyser (2016) indicate that corporate brand identity after being communicated, results in the image and also in the formation of a reputation for a brand. According to Chernatony and McDonald (2011) it is essential to recognise that while advertisers instigate the process of brand creation (the brand as an input), it is the consumer who forms a mental vision of the brand (brand as output), which can be different from the planned identity. In a more recent study, Roy and Barnejee (2014) develop a model for identifying and measuring the gap between communicated identity and perceived image not only by consumers but also by channel 
members. The authors reported the importance of identifying the gap between the initially planned identity and its respective image, because when this gap is recognised, it is easier for the marketing managers to take possible measures to eliminate it.

The study of Hoss and Harradine (2010) investigated potential misalignments between the identity created for a clothing brand and the way it was perceived by its younger consumers. It was reported that the differences were found between the way the brand was intended to being perceived and the way consumers actually perceived it. Additionally, they indicate that these differences in perceptions can create barriers during the process of making purchasing decision. Thus, some authors have created models to assist in the development and management of brand identity (Ghodeswar, 2008; Silveira, Lages and Simões, 2013; Urde, 2013).

There are several studies about the identity management of product brands (Xie and Boggs, 2006), and corporate brands (Shultz, Antorini and Csaba, 2005; Coleman et al., 2011; Urde and Greyser, 2016). In a more recent literature, also studies on place brand identity are presented, like countries (Ruzzier and Chernatony, 2013); cities (Henninger et al., 2016) or regions (Castro and Giraldi, 2015). For example, the study by Rojas and Méndez (2013) developed a model of country brand management, where dimensions such as economy, tourism, geography, culture, society, science and government have been frequently analysed. For Ruzzier and Chernatony (2013) the management of the brand identity of a country should analyse the following elements of a given nation: benefits, mission, vision, values, personality and preferences. Additionally, the authors report that all these elements are in constant communication with several stakeholders.

The large number of stakeholders that must be considered for the management of place brands occurs because of interorganisational relationship, in which many organisations share a 
single brand developing a business-to-business cooperation (Agostini and Nosella, 2017). The brand sharing happens when it is developed in a unique identity for the partners and its management is governed by an independent identity (Tregear and Gorton, 2009).

As a result, this type of relationship is composed by a large number of stakeholders, so place brand management become closer to corporate brand management processes than to products brands (Ruzzier and Chernatony, 2013; Rojas-Méndez, 2013). Still in relation to the management of place brands, Kavaratzis and Hatch (2013) report that it is essential to consider the constant dialogue between the internal and external environment when constructing the identity of places brands.

The literature on place brands also encompasses studies about brands for sectors (Ringer et al., 2013; Capellaro and Giraldi, 2015). Several countries have already developed this type of brand for internationalisation of their sectors (Aichner, 2014). In Brazil, the Brazilian Agency for the Promotion of exports and investments (Apex-Brasil) is responsible for developing and managing sectorial brands (Lourenção and Giraldi, 2017). This type of brand is created by ApexBrasil in conjunction with the associations representing the sectors and it should be used at international events. In context to this, the creation of sectorial brand identity, as well as for corporate and country brands, also involves the understanding about their various stakeholders, which are considered in the model proposed by Lourenção and Giraldi (2017) recently. In the study, these authors proposed an identity model specifically for development and managing of sectorial brand. The model addresses four dimensions of analysis: (i) components of identity; (ii) components of communication (iii) identity delivery elements (iv) external factors that influence the identity. Each dimension contains a number of elements that should aid in identity development and management for the brand in the industry. This model is used as a baseline for 
139 the interview script developed for the data collection of this study, whose focus is on sectorial 140 brands.

\section{Sectorial Brands}

Capellaro and Giraldi (2015) stated that a viable strategy for sectors that are not favored by 145 the images and brands of their respective countries but that are internationally competitive in 146 terms of its quality and differentiation attributes would be to create an independent or specific

147 brand for the sector and to use it in promotional activities. Furthermore, the authors report that, 148 instead of using the country brand identity for support, it may be necessary for some sectors of 149 the economy to create and manage independent brands of their own, because the associations 150 created by a country-brand may not be comprehensive enough and potentially restrictive. For

151 example, "Brazil IT +" brand, reported in the study by Ringer, et. al. (2013), representing the 152 Brazilian technology sector abroad.

However, the sectorial brand is not always built to unlink the sectors from the national 154 image. Lourenção and Giraldi (2015) reported the process of creating the brand of the Brazilian 155 jewelry sector, Brazil Gems and Jewelry. The brand aims to promote the sector internationally. 156 Considering that, Brazil is one of the countries with the largest variety of gemstones, some of 157 them, rare and / or exclusive, such as topaz imperial (IBGM, 2015). In this sense, the sector's 158 image is consistent with some attributes of Brazil's country image abroad such as diversity, 159 colours and joy (Sutter et al., 2014).

In addition, it is important that countries invest in the creation of sectorial brands, since it 161 allows any company that is part of a given sector to use it for promoting products (Lourenção 
162

163

164 165

166

167

168

169

170

171

172

173

174 175 2016).

176

177

178 179 180 181 price premium for Vidalia Onions.

182

183

184

and Giraldi, 2017). Castro and Giraldi (2015) indicate that sectorial brands are one of the possible types of shared brands. In Brazil, shared brands are divided into: (i) sectorial brands; (ii) collective brands; and (iii) geographical indications (Castro and Giraldi, 2015).

Sectorial brands are less restricted than other types, such as geographical indications (Charters and Spielmann, 2014) and collective brands, which requires a proof of quality to use the brand in its products (Castro and Giraldi, 2015). The criteria for the use of shared brands, as well as the terms used for their classification, vary from country to country (Castro and Giraldi, 2015). However, some studies report cases of brands that have the purpose of promoting the sector of their countries internationally, for leverage to export their products.

Bassols (2016), for example, reports the development case of the Juan Valdez brand, which was developed by the National Federation of Coffee Growers and is responsible for representing Colombia's coffee sector. The brand was recognised as the best-known advertising character in the USA and after the national flag, Juan Valdez is the country's best perceived symbol (Bassols,

Another case reported is in the study of Carter, Krissof and Zwane (2006) about the brand Vidalia Onions, these onions are grown in select counties in the state of Georgia, in the United States. They have historically been differentiated from competing onions on the basis of taste. The authors indicate Vidalia onion growers have been extremely successful in defending their brand, even as acreage has risen. The brand contributes to sector promotion and maintenance of a

Furthermore, sectorial brands can also contribute to improve country image. The study of Kilduff and Nuñez-Tabelez (2014) reports that in Spain, the Spanish Institute of Foreign Trade (ICEX) has also been concerned with developing sectorial international promotion actions. The 
authors mention that this initiative began as a reaction to the negative and undefined image associated with Spanish products. At first, the brand Made in Spain was responsible to promote all sector, but with the intention to define better and specify sectors image, ICEX began developing sectorial brands, such as: Food \& Wines from Spain, Interiors from Spain, Fashion from Spain, America Reads Spanish and Spain: Technology for life. These sectorial brands mainly focused promotion within the United States and Russia.

Tregear and Gorton (2009) present other reasons why sector brands can be developed: (i) by offering small businesses the means to achieve a brand positioning with a strong international presence from the outset, such as, helping small companies to be internationally recognised and to increase their export volume; (ii) to have the attributes of its products linked to the country of origin and (iii) to stimulate collective marketing actions. In Brazil, only in the last ten years sectorial brands have gained strength (Castro and Giraldi, 2015).

However, despite these benefits the literature in this area presents some challenges in the development of brands for sectors. Thus, an initial barrier is presented by organisations who fear that companies which do not contribute to collective action take advantage of the benefits it brings (Uzea and Fulton, 2014). In the development phase of the brand, another challenge can also be found, that of developing a unique and appropriate identity for all participants (sectorial associations) that are represented by the brand (Tregear and Gorton, 2009).

This challenge is evident in the study of Carter, Krissof and Zwane (2006), which indicates the case of the sectorial brand Washington Apples. The authors comment that these producers have historically used promotional activities to inform consumers of the distinguishing characteristics of their apples. However, the authors argue that unlike the case of Vidalia Onions, the Washington Apples have not been able to maintain coordination over funding for these 
activities. Carter, Krissof and Zwane (2006) indicate that the local growers refuse to use this brand because they consider it too generic and began to develop promotional actions in smaller groups of apple growers, because it is easier to coordinate and to share specific characteristics. sectorial brand to represent them, called Brasil Fashion System, the case of the present study.

\section{Brasil Fashion System brand}

216 Sectorial brands have gained popularity and strength for the past decade in Brazil sectorial

217 (Castro and Giraldi, 2015). In order to facilitate the access of Brazilian companies to the key

218 international markets, identifying prospects for business exports and improve global perception 219 about Brazilian companies, Apex-Brasil has developed individual projects to promote Brazilian 220 sectors, and encourage the creation of brands to represent them, currently there are 72 sectorial 221 brands from these projects (Apex-Brasil, 2017). Some examples of these brands in Brazil are: 222 Brazilian Beef that represents the Brazilian Association of Meat Exporting Industries; Brazil 223 Let's Bee representative of the Brazilian Association of Honey Exporters; Wines of Brazil 224 created to promote the Brazilian Wine Institute and Brasil Fashion System, representative of 225 seven associations of the Brazilian fashion sector (Apex-Brasil, 2017).

The Brasil Fashion System brand was developed to represent the Brazilian fashion sector.

227 The brand encompasses the seven associations that compound the sector, they are: (i) Brazilian 228 Association of Stylists (ABEST), Brazilian Textile and Apparel Industry Association (ABIT), 229 Brazilian Footwear Industries Association (ABICALÇADOS), Brazilian Association of Leather, 230 Footwear and Artifacts Companies (ASSINTECAL), Center of the Industries of Tanneries in 
231 Brazil (CICB), Brazilian Association of the Industry of Leather Goods and Travel Articles 232 (ABIACAV) and Brazilian Institute of Gemstones and Precious Metals (IBGM).

233 According to the Brazilian Institute of Gemstones and Precious Metals (IBGM, 2015), the 234 sectorial project takes into account three aspects: the governmental (represented by Apex-Brasil), 235 the sectorial (represented by the associations representing the sector) and the private sector 236 (represented by the companies supported). The participation of these three groups is important to 237 ensure the involvement of all stakeholders and maintain its suitability and balance. Since the 238 creation of Apex-Brasil, partner entities have been encouraged to create brands for the sectors 239 that represent them. Thus, the project for the Brazilian fashion sector developed by Apex-Brasil, 240 together with its associations, created the brand 'Brasil Fashion System' in 2012 (Gad, 2012). This brand was created to represent the seven associations of the Brazilian fashion sector. umbrella brand, which encompasses all seven sector brands used individually by associations, as illustrated by Lourenção and Giraldi, (2017) in Figure 1.

\section{[Insert Figure 1 about here]}

A brand book was developed outlining main attributes of the Brasil Fashion System brand, by

250 the Gad Company, to create unique identity. The brand book indicates that the Brazilian Fashion 251 System's visual identity, despite not presenting the Brazilian colours is strongly based on 252 national attributes, thus, the brand is defined as: (i) authentic, considering that authenticity refers 253 to the Brazilian way of life and also to the way national fashion is created through knowledge, 
254 techniques, methods and own way that reflects a unique personality; (ii) vibrant, attribute given 255 to represent the energy and enthusiasm of all the fashion manifestations of the country; (iii) 256 diverse, characteristic that expresses the dimensions, abundance, and multiplicity of Brazil; and 257 (iv) sustainable, which indicates the search for a sustainable development model in the Brazilian 258 fashion value chain, so that partnerships are formed with a focus on the use of resources and 259 inputs that minimize the impact on the environment and the development of processes and more 260 efficient production systems (Gad, 2012).

261 The theoretical reference here allows to understand that for a brand to have its image formed in 262 the mind of the consumer in a particular way, it is necessary that there is a congruence between 263 the initially planned identity and the image perceived by the target audience (Roy and Barnejee, 264 2014). Although the Brazilian fashion sector already has a project developed for the planning of 265 its brand identity, it does not yet have a consolidated image abroad (Sutter et al., 2014). One way 266 of mitigating the challenge of creating a unique identity for all the involved parties; is to identify 267 the brand elements that are appropriate for each of the separate entities (Iversen and Hen, 2008; 268 He and Balmer, 2014). To do this, in the present study, it is proposed to identify similar 269 characteristics among the partners of Brasil Fashion System sector brand. Therefore, it is 270 expected that these identified characteristics will be considered suitable to represent all its 271 partners.

272

\section{Methodology}

274 The methodology for this study is divided into three parts. The first concerns with the 275 presentation of research methods, study protocol and its proposition. The second presents how 276 the data was collected and the third presents the proceedings utilized in data analysis. 
277

278

279

280

281

282

283

284

285

286

287

288

289

290

291

292

293

294

295

296

297

298

299

\section{Research Methods}

For the present work, the qualitative exploratory research method is used. The qualitative nature chosen is justified by providing better insight and understanding of the context of the problem (Malhotra, 2006). Considering that the attributes of the brand identity presented by the interviewees are characterized in a more abstract way, it is necessary that the data acquired in the analysis must be detailed, which can be effectively obtained by a qualitative data.

Based on the study of Pereira et al., (2016), a study protocol is also proposed to facilitate understanding of the steps of the present research (Table 1).

\section{[Insert Table 1 about here]}

As showed in the Table 1, a proposition was prepared, whose validity will be analysed in the light of the results presented in next section. Thus, the following proposition is defined: There are characteristics of the brand identity elements that are common among the associations that compound the Brasil Fashion System brand. This proposition was based on the study of Iversen and Hen (2008), since they mention the importance of identifying key values or similarities that capture the complexity of all brand partners, for the creation of an umbrella brand identity. Thus, it is important that, to define the attributes of a sectorial brand, there are similar attributes represented among the associations.

\section{Data Collected}

For the data collect in-depth interviews were applied. As the purpose of this kind of interviews is to provide in-depth and rich information, it may involve just small samples and it is not necessarily representative of large population (Malhotra, 2006). In relation to this, seven in- 
depth interviews were conducted with all associations that are represented by the Brasil Fashion System sector brand.

The interviews duration was on average about 50 minutes each of them. To facilitate the identification of the interviewees, a coding system was place in effect, which has been used to present findings of this study. Thus, the terminology defined here uses the first letters AS to represent the associations. Table 2 provide information on: i) products commercialized by industries associated, ii) codification; and iii) each position held by interviewers. It is relevant to mention that the managers were selected to be interviewed because they are responsible for the development and management of Brasil Fashion System brand.

\section{[Insert Table 2 about here]}

The questions for data collection were based on each of the attributes that form identity model of a sectorial brand, defined in a study conducted by Lourenção and Giraldi (2017). As a result, they indicate that there are fourteen elements that should be used to elaborate the brand identity: personality, positioning, product, country of origin, orientation to the buyer, marketing campaign, visual identity, stationery, promotion tools, relationship with buyers, product performance, environmental and attitudes conditions and buyer's behavior. In addition, these elements were divided into four distinct dimensions and also used to present the results: (i) identity components; (ii) communication components; (iii) elements of identity delivery and (iv) external factors that influence identity.

Below Table 3 outlines the data collection approach and relates the sectorial brand identity elements (Lourenção and Giraldi, 2017) to the questions elaborated in this study to establish the similar characteristics among partners of the sectorial brand studied. The interviews were recorded for later transcription of the data to Word document. 
[Insert Table 3 about here]

325

326

327

328

329

330

331

332

333

334

335

336

337

338

339

340

341

342

343

Data Analysis

The recorded interviews were uploaded to the software named Express Scribe, where they were transcribed for data analysis. The transcription of the interviews made it possible to develop the categorisation of respondents' responses, which is one of the stages of qualitative research used in this study (Riege, 2003). The categorisation consists of grouping the raw data into aggregated and organised units that allow descriptions of characteristics pertinent to the study objective (Bardin, 2011). Thus, the answers obtained from the seven managers were grouped into categories associated to each of the fourteen elements of the sectorial brand identity model, proposed in the study of Lourenção and Giraldi (2017).

After that, each category was analysed and then we extracted the main words for each response (Bardin, 2011). The summarisation of the sentences was important because after doing it, the interviewees' summarised answers were compared among them to identify similar responses, that may indicate common characteristics among the associations partners and contribute to the construction of a consistent sectorial brand identity.

A discussion section of the results is also presented, in which the triangulation of the data was developed through the comparison of data collected in the present research with the studies mentioned in the literature review section (Jack and Raturi, 2006; Bardin, 2011). The data's triangulation contributes to the evaluation of this study's proposition.

To better understand the methodology section, a flowchart of the research methodology is proposed based on the study of Panigrahi and Rao (2018), as presented in Figure 2. 


\section{Results}

The results obtained from the interviews with the managers indicate that there are no elements 352 that are common among all the associations that make up the Brasil Fashion System. 353 Nonetheless, there are some elements and management actions that are carried out by most of 354 them, here they are present briefly, and in the next section more details are presented. So, most 355 common sectorial brand identity elements and managerial actions among the associations are: 356 innovation, the United States as a target market; products of the sector recognised for quality and

357 diversity abroad; Brazil's country image associated with the brand of the sector; market-oriented 358 management; use of the sectorial brand only in cooperative campaigns; logo should 359 communicate quality; use of websites to promote their brands; development of relationship 360 programs with international buyers; measurement of sales performance of products abroad; Italy 361 and China as competitors; the managers believe that the image of Brazilian products abroad has 362 improved and evaluate consumer behavior before and after purchase.

It is really important to note that the results presented in this section are related to sectorial 364 brand identity, so the data shows the internal perception of sectorial brand managers that can be 365 different from the sector international image. As indicated by Buhmaan e Ingenhoff (2014), the 366 identity represents the attributes and respective self-perception and the image is the perception 367 among foreign publics.

To facilitate the understanding, a visual representation in Table 4 relating all the dimensions 369 and their respective elements of the sectorial brand identity with the answers of the seven 370 associations has been presented. Each line of the Table 4 represents a different brand element 
which is based on the work of Lourenção and Giraldi (2017) and each column represents an association of the sector.

[Insert Table 4 about here]

As shown in Table 4, the construction of the identity of a sectorial brand is divided into four

dimensions: i) identity components; ii) communication components; iii) brand identity delivery

377 elements; iv) external factors that influence brand identity (Lourenção and Giraldi, 2017).

378 Thus, the results are also separated into these four dimensions to improve their understanding 379 and further relate relevant discussion.

\section{Results for identity components}

382 The identity components are composed of managerial decision attributes and is used to 383 characterize the product and/or service of a certain organisation (Lourenção and Giraldi, 2017). 384 The dimension called identity component is composed by five elements, namely: personality, 385 positioning; product; country of origin and market orientation. The relevance of each of these 386 elements is presented throughout this section along with the explanation of its results. The BFS 387 brand personality has four defined attributes: vibrant, diverse, sustainable and authentic. So, the 388 result for the personality element indicates whether these attributes were considered adequate to 389 represent each of the seven BFS partner associations individually and also what are the similar 390 personality attributes among them.

391 As presented before in Figure 1, in BFS brand hierarchy each association has a sub-brand, that 392 is used individually. So, for these sub-brands an individual personality was developed by its own 393 brand management. However, after analysing the elements defined for the personalities of the 
sectorial sub-brands (Figure 1), it was perceived that they are different from the personality created for the general brand of the sector, the BFS, which they belong to. For example, only one of the seven associations uses the BFS vibrant and authentic elements for its communication

397 (which are part of BFS brand's personality), and only two of the seven associations use the 398 sustainable element. Thus, it is possible to perceive that there is a divergence between the 399 elements communicated by the personality of the sectorial brand BFS and the elements 400 communicated by the sector sub-brands of its partners (Figure 1). This fact could generate a not 401 well-defined communication abroad, resulting in a confused international image about the sector. 402 Additionally, the responses indicated that not all associations can be adequately represented 403 by the BFS brand's personality elements (vibrant, diverse, sustainable and authentic). For 404 example, the AS6 has credibility, assurance, trust, agility and business as part of its personality, 405 but none of these are transmitted by the attributes defined for the personality of BFS brand that 406 should represent it.

407 However, it is possible to notice that there are common attributes that would represent some 408 409 associations together. For example, the innovation element is suitable for AS1, AS2; AS3 and AS5, the diversity element is appropriate for AS1; AS4 and AS7, design is adequate for AS1; AS3 and AS7. Finally, there are others elements that could be suitable for two associations at the 411 same time. Despite this, no element was found that was common among all associations.

412 For the positioning element, each country is considered as a target market for the association 413 considering the context of sector firms products exportations. In this way, for each association its 414 target markets were indicated. It was noted that United States is a target market for almost all 415 associations, except for AS3. So, contrary to what the individuals representing associations have 416 stated throughout the interviews, there are identical target markets among them, in which events 
could be held to use the Brasil Fashion System brand. However, although the target country may be the same, the promotional actions may not be similar.

The product element represents the difference in products being exported by the industries of each of the associations according to the responses to the question 'by what characteristic that their products were known abroad'. As a result, it was possible to perceive a great distinction between the characteristics mentioned by the associations, indicating that their products are quite different. In relation to this, interviewees representing AS7 and AS1 cited 'diversity' as a common characteristic. AS5 and AS6 interviewees also mentioned 'quality' as a common attribute among their products. In addition, AS6 and AS7 also have the common design attribute as a qualifier for their products.

The country of origin element is indicated in the fourth line of the Table 4. Five associations considered that the products exported by the industries that compound their association are related to the characteristics of the country of origin (AS1, AS2, AS3, AS4, AS7) while the other two say that Brazilian attributes are not found in their products (AS5, AS6).

The market orientation element indicates whether the associations interviewed help their companies to target the international buyer, that is, if the companies make adaptations in their export products to be adapted to the international consumers preferences. The Table 4 shows that the responses among associations are similar and that they all do the analysis of the international market so that the industries of the sector can export products suited to them. For example, the manager of AS6 reports that some Brazilian footwear industries that intend to export them to Russia need to make adaptations, since Brazilian shoes are not suitable for winter in Russia, so they need to produce shoes that fit this demand. The manager also comments that the shape of the Brazilian shoe is not suitable for Chinese's feet, so it is not possible to export the same shoe 
440 that is sold in Brazil, it is necessary to have a specific production to attend the Chinese

441 consumer, and thus, to accomplish the market orientation, discussed in this topic.

442 Results for communication components

443 In this topic, the results for the communication components of the identity of a sectorial brand

444 are discussed. These attributes are also part of the identity model for sector brands proposed in

445 the study of Lourenção and Giraldi (2017). So, the model indicates that first the identity

446 components are defined by the managers and later it is necessary to define how the identity

447 communication will be performed for the external market, which is discussed in the present

448 topic.

449 The communication components dimension is composed by four elements, namely: marketing 450 campaign; visual identity; stationary and promotion tools (Lourenção and Giraldi, 2017). So, in 451 the marketing campaign element, is indicated how the Brasil Fashion System brand is used by 452 associations. In this way, it is possible to notice that AS1, AS2, AS4, AS5 and AS7 have similar 453 use, being made with two or more associations and developing meetings before the events to 454 define how the brand will be potentially used. The AS3 and AS6 associations stated that they are 455 not currently using the fashion industry brand in their events abroad. The AS7 was the only one 456 that stated that it already used the sectorial brand in an event abroad where it was the only 457 association present.

458 The visual identity element indicates the attributes that the associations would like to be 459 communicated to represent them abroad by the brand's visual identity. It is possible to perceive 460 that most of the attributes chosen by them were distinct. Only two attributes chosen to be 461 communicated by BSF brand's visual identity were similar among some associations: quality and 462 contemporaneous. The associations managers of AS1, AS4, AS5, AS6 relate that these 
associations want that the exported products by its industries should be seen in international markets as quality products. Additionally, the managers of AS1 and AS3 indicate that contemporaneous is also an attribute that their associations would like to be communicated. So, for some associations these attributes should be communicated by the semiotic resources in sectorial brand logo but for the other ones these attributes are not mentioned (AS2; AS7).

For the stationery element, all associations, with the exception of AS5, commented that no type of stationery was ever developed for the Brasil Fashion System brand. The AS5, however, stated that the stationery for the sectorial brand is developed for promotional activities abroad.

The promotional tools element indicated the tools used by the associations to communicate the Brasil Fashion System brand internationally. It was identified that only AS1, AS2 and AS7 indicated common promotion tools between them. The four remaining associations reported divergent forms of sector brand promotion.

\section{Results for brand identity delivery elements}

In this dimension the elements responsible for delivering the brand are discussed. These attributes are also part of the construction of their identity, since after their components are defined and communicated it is necessary that there is also the contact of the brand, that is, contact of the organisation and its products, with the consumer. This action is called brand identity delivery elements by Lourenção and Giraldi (2017).

The first element in this group is the relationship with the buyers. The responses indicate that the attitudes of all the associations were similar among them because all associations seek to encourage the relationship with the international buyer. To do this, they organise business rounds, support participation in international fayre and invite international buyers to come to 
Brazil to know the industries of the sector. The manager of AS7 commented that their association sometimes pays for the flight ticket and hotel for international buyers to come to Brazil during festive seasons (carnival, for example), so this is an incentive and they accept the invitation. In these cases, when the buyer comes, they take them to know the industries of the sector, but it is not always that they succeed in ensuring confirmed business deals. For example, an international buyer comes to Brazil, go to business international fairs in this country and do not close any deal with Brazillian firms to sell its products abroad.

For the product performance element, it was possible to verify that all associations have the performance of products exported by their industries verified abroad by statistical data reports. Some managers commented that product performance can also be observed through informal conversations with traders and buyers themselves. For example, the associations managers go to an international fayre and there, talking to international buyers, they are able to know about the acceptance of Brazillian products by the perspective of international buyer. The same occurs when association managers talk to the Brazillian tradespeople to know how it is going the commercialization of his firm's products, that is, if they are selling well or not in international market. One of the managers specifically outlined that when international buyers face difficulties in the relationship with Brazilian industries, they talk to the association. For them this is a security, as they know that the association will respond to them. When this occurs, the association contacts the industry and seeks to resolve the problem. Based on these interactions with both the international buyer and the seller, it is also possible to know, although informally, whether the product is being accepted abroad.

\section{Results for external factors}


Finally, the fourth dimension presents evaluation of the external factors that influence the brand identity of the sector. The first element to be analysed in this group is the competitors' action. The countries or regions mentioned as competitors for the associations interviewed were

512 added to Table 4. It was established that AS2, AS3, AS5, AS6 and AS7 have a common 513 competitor, that is China, classified by the associations as a competitor in the area of scale 514 production and low price. It has also been found that AS4, AS5, AS6 and AS7 have a common 515 competitor, in Italy. The associations classified Italy as a competitor in the area of quality and value added. Colombia is also a joint competitor for AS2 and AS5.

517 About the conditions of the environment in which the industry is included, the associations 518 were asked their perceptions about the image of Brazil. In this way, it was possible to perceive 519 that AS1 and AS7 believe that Brazil has a positive image abroad. AS2 and AS6 responded that 520 the Brazilian image varies greatly from one market to the other and may be positive or negative 521 according to the market to which it refers. AS3 and AS4 noticed an improvement in the Brazilian 522 brand image, since there was already some kind of prejudice with the domestic products that 523 were exported and, currently, this no longer exists. Finally, AS5 identified current economic 524 crisis that, Brazil is experiencing, could potentially influence its image abroad, however, the 525 interviewee believed that international buyers perceive this crisis as temporary, and also other 526 countries in similar situation globally. With this, it is possible to perceive that the interviewees 527 perception about the Brazilian image abroad is an attribute that has great variation.

528 The buyer's behavior element analyses two factors: i) evaluation of the behavior of its 529 international buyers before entering the market; ii) evaluation of the buyer's opinion after 530 making the purchase. Regarding the first sub-item, as all associations stated they evaluate buyer's 531 behavior prior to undertaking international activities. Regarding the second sub-item, AS1 and 
532 AS5 said that there has never been any kind of prejudice from international buyers against Brazil 533 as country of origin of the products. In turn, AS2 and AS7 mentioned that they have heard 534 complaints from international buyers about the delay in delivery of products exported by the 535 industries that are part of their associations. Interestingly, as for AS4, Brazil is only exporting 536 because of the high dollar price; and for AS5 it is increasingly difficult to communicate the 537 value-added attribute to international buyers, since they are unable to link Brazil to the quality 538 attribute.

\section{Discussion}

Regarding the management of the brand identity of the sector as a whole, it is important

542 that the four dimensions of the sector identity model (components of identity, communication 543 components, delivery elements and external factors) can be developed and implemented in a 544 harmonic way between all brand partners (Lourenção and Giraldi, 2017). Therefore, to achieve a 545 consolidate sectorial brand identity in international market it is essential that: i) be defined and 546 used same brand identity components by all brand partners; ii) brand identity communication 547 components have to be similar between the associations partners, that is, the promotion tools 548 used to communicate the brand, for example, would be the same for all associations iii) the

549 delivery elements such as relationship with buyer should be implemented in the same way for all 550 associations; and iv) the external factors should be managed in a consistent way between 551 associations.

552 In contrast, as state by Iversen and Hen (2008), it is important to identify some similarities 553 among brand partners to manage its brand identity. Therefore, considering this, the model of 554 Lourenção and Giraldi (2017) was applied as a management tool for brand identity, to identify 
555 similar characteristics among the partners. The specific results for the Brazilian fashion sector

556 (Table 4) indicate that the proposition of the present study can be confirmed, since there are 557 characteristics of the elements of sectorial brand identity that are common among the 558 associations that make up the Brasil Fashion System brand.

559 However, there are also several characteristics of brand identity elements that are not similar 560 among associations and it was also observed that not all managerial actions by the associations 561 are implemented in a similar way, when considering the four dimensions highlighted in the 562 model of Lourenção and Giraldi (2017) (See its application on Table 4).

563 The results also indicate that the associations partners have different attributes and managerial 564 actions because for some of them it is not suitable to communicate some attributes defined for 565 BFS brand. The attributes chosen for the brand of the fashion sector, are not those that the 566 associations would choose primarily. However, due to the need to choose attributes that 567 represent the set of seven associations, they were considered adequate by some of the 568 associations for communicating attributes linked to the country of origin that is something in 569 common between them. Despite this, two of the seven association indicates that the Brazilian 570 attributes were not suitable to represent them.

571 This divergence between characteristics of partners identity and managerial actions made 572 more difficult to consolidate the Brasil Fashion System brand identity abroad. So, Brazilian 573 fashion sector has not consolidated an identity abroad yet (Sutter et al., 2014).

574 Another point is that, a sectorial brand identity diffuse abroad could results in divergent 575 images between the international target markets of each of the associations. The difference in the 576 image perceptions can occur because the brand identity is not well defined within the fashion 
577

578

579

580

581

582

583

584

585

586

587

588

589

590

591

592

593

594

595

596

597

598

599 sector (Sutter et al., 2014), so each association will divulge the identity in a different way from one another and will generate divergent images for each target audience.

In order to improve understanding on this subject, the Figure 3 is proposed, which indicates the current situation of the identity and image of the Brasil Fashion System brand abroad and the ideal formation of how it should occur. The different formats in left side of the Figure 3 represents the divergence between associations' individual identities and the different formats in the right side of the Figure 3 represents the distinct images formed by each its respective association's individual identities. The model was based in some literature theories that indicates that the image is the result of the identity communication process (Roy and Barnerjee, 2014; Dinnie, 2016).

\section{[Insert Figure 3 about here]}

So, even though the contribution of sectorial brands has already been highlighted in the literature (Castro and Giraldi, 2015; Lourenção and Giraldi, 2017), considering the case of BFS brand, as well as, the divergence between its partners and the difficulty to consolidate the brand abroad, it is possible to question if all the partners associations should even try to use this sector brand. For some of them it may be more advantageous to use only its sector sub-brands (Figure 1) considering that the attributes communicated by Brasil Fashion System differ from the main elements desired for many individual identities of the associations.

In consonance, as state by Dinnie (2017), place brands should be constructed in the light of their specific target audiences. So, the use of Brasil Fashion System brand is not adequate for all partners since some of them have different identity attributes and also different target audiences. 
600 Thus, maybe for these partners it should be more adequate to use just their sectorial sub-brands

601 (Figure. 1) because, by doing this, they will be providing a brand for its specific target audience, 602 with more adequate attributes for their communication's objectives.

603

604 Conclusion

605 Sectorial brands are made to promote products of country sectors in order to incentivise the 606 exportation (Castro and Giraldi, 2015). To achieve this, it is necessary that the communicated 607 sectorial brand identity results in a positive and a consolidated image for the brand abroad (Roy 608 and Barnerjee, 2014; Dinnie, 2016). To obtain a consolidated image, it is necessary to have a 609 good management of the sectorial brand.

610 The first step for this management is the development of a brand identity, being necessary to 611 verify what attributes should be communicated by the brand. For doing this, it should be verified 612 what are the common attributes among the associations that will be represented by the brand 613 (Iversen and Hem, 2009) and this is what was carried out in our study, which has focused in 614 analysing similar elements characteristics of brand identity among the associations that 615 compound the Brasil Fashion System brand. The findings lead to the conclusion that: i) There are 616 common attributes to two or three associations at the same time, but it was not possible to find 617 common attributes to all seven organisations concurrently. So, besides the existence of some 618 common attributes, the associations partners have also distinct characteristics and managerial 619 actions in relation to their sectorial brand identity; ii) this divergence of characteristics and 620 managerial actions regarding the brand identity could result in a non-consolidated sectorial brand 621 identity abroad. This result is in consonance with Sutter et al., (2014), who indicate that the 622 Brazilian Fashion industry has faced some difficulties while consolidating its identity 
623 internationally; iii) it was also possible to verify that a diffuse brand identity could result in 624 distinct brand images abroad for different target audiences (Figure 2). This conclusion was based 625 on communication models such as Roy and Barnejee (204) and Dinnie (2016); iv) moreover, for 626 sectorial brand cases with a great divergence among brand partners, the creation of sub sectorial 627 brand specific for each partner could bring better results, since in this way brands could be 628 created with more suitable attributes for each partner, which will better suit their target 629 audiences. This result is in consonance with Dinnie (2017), who indicates that place brands 630 should be constructed in the light of their specific purpose and target audiences; v) in addition, it 631 is possible that in sectors with a smaller number of associations or participants, it may be easier 632 to build a sectorial brand, given the less difficulty in finding similar attributes to compose their 633 identity. This result is in agreement with the Tregear and Gorton, (2009) research, that shows the 634 challenge of create a unique identity to represent all brand partners.

635 It is believed that this study was able to obtain practical and theoretical contributions. The 636 theoretical contribution occurs since in the literature have been found only studies that seek to 637 assist in the creation and sectorial brand management proposing models (Lourenção and Giraldi, 638 2017), but no studies were found showing the managerial tools application for possible solutions 639 to the problems founded in the management of this brand type. Considering that consolidation 640 and standardisation of sectorial identity abroad is considered a challenge for the Brazilian 641 fashion sector (Sutter et al., 2014), the present study contributes to identify possible management 642 solutions for the identity of sectorial brands, showing what would be good practices in the case 643 of a great divergence in the characteristics and managerial actions among the sectorial brand 644 partners. 
645

646

647 in managing the sectorial brand, mainly due to the existence of diversity in the partner

648 associations identities. Even after the elaboration of Table 4, it was not possible to trace

649 congruent elements between the associations for the formation a unique identity, because

650 although there were common attributes among some of the associations, it was not possible to

651 establish attributes that were common to all of them. So, the present study contributes to the

652 managerial practices when proposing a conceivable resolution for the identity consolidation

653 challenge, showing that in this case it would be better to use just the sectorial sub-brands for each

654 association (See Figure 1).

655 As highlighted in the study by Iversen e Hen (2008) it is clear the importance of elaborate 656 coherency of brand identity among different entities, so that it can better represent all of them 657 and to consolidate its sector identity abroad (Sutter et al., 2014) and it could be done by the 658 sectorial sub-brands already presented in Figure 1, but not by the brand BSF, due to great 659 divergence among its partners.

660 As a limitation, it can be pointed out that the study was carried out with only a single sectorial 661 brand. Future studies can verify whether other sectorial brands that are formed by only one 662 association can define more consolidated attributes for their communication abroad. Also, for 663 future studies, it is suggested to verify how the process of building sectorial brands should occur, 664 since there is still a great divergence between the attitudes taken towards each of the elements, 665 by the associations of the Brazilian fashion industry, thus, the communication and delivery of 666 brand value occurs in a different way among them.

\section{References}


Agencia de Brasileira de Promoção de Exportação e Investimentos. Available at < http://www.apexbrasil.com.br/participe-dos-nossos-projetos-com-as-entidades-setoriais>. Access on March 18. 2017.

Agostini, L. and Nosella, A. (2017), “Interorganizational Relationships in Marketing: A Critical Review and Research Agenda", International Journal of Management Reviews, Vol. 19 No 2, pp. 131-150.

Aichner, T. (2014), "Country of origin marketing: a list of typical strategies with examples", Journal of Brand Management, Vol. 21 No 1, pp. 81-93.

Bassols, N. (2016). "Branding and promoting a country amidst a long-term conflit: The case of Colombia", Journal of Destination Marketing \& Management, Vol 5 No 4, pp. 314-324.

Barjolle, D.; Quiñones-Ruiz, X. F.; Bagal, M. and Comoé, H. (2017). "The hole of the state for geographical of coffe: case studies from Colombia and Kenya". World Development, Vol 98 No 1, pp. 105-119.

Buhmann, A. and Ingenhoff, D. (2014). "The 4D model of the country image: an integrative approach from the perspective of communication management". The international communication Gazette, Vol 77 No 1, pp. 102-124.

Bruwer, J. and Johnson, R. (2010). "Place-based marketing and regional branding strategy perspectives in the California wine industry", Journal of Consumer Marketing, Vol 27, pp. 516.

Capellaro, A. F. and Giraldi, J. M. E. (2015). "Sector brand development in Brazil: prospects and challenges”. Revista Brasileira de Gestão e Desenvolvimento Regional, Vol 11, pp. 353-375. 
Carter, C., Krissof, B. and Zwane, A. P. (2006). "Can country of origin labeling succeed as a marketing tool for produce? Lessons from three case studies.”. Canadian Journal of Agricultural Economics, Vol 54, pp. 513-530.

Castro, V. A., and Giraldi, J. M. E. (2015). "Estratégias de marcas para setores brasileiros: uma análise das diferenças conceituais entre indicação geográfica, marca coletiva e marca setorial.’. Encontro de estudos em estratégia, Brasília, DF, Brasil, 7.

Charters, S. and Spielmann, N. (2014). "Characteristics of strong territorial brands: the case of champagne", Journal of Business Research, Vol 67 No 1, pp. 1461-1467.

Chernatony, L., Mcdonald, M., and Wallace, E. (2011). “Creating Powerful Brands”. Oxford: Butterworth-Heinemann Press.

Coleman, D.; Chernatony, L.; and Christodoulides, G. (2011). "B2B Service brand identity: Scale development and validation”. Industrial Marketing Management, Vol 40, pp. 10631071.

Dinnie, K. (2008). "Nation Branding: concepts, issues, practice”. Oxford: ButterworthHeinemann Press.

Dinnie, K. (2016). “Nation Branding: concepts, issues, practice”. 2nd ed. Routledge: London.

Dinnie, K. (2017). Contingent self-definition and amorphous regions: a dynamic approach to place brand architecture. Marketing Theory, 18 (1), 31-53.

Gad. (2012). Cases: Brasil Fashion System. Acesso em: out. 2016. (Disponível em: http://gad.com.br/PT/cases/detalhe-case/94).

Ghodeswar, B. M. (2008). "Building brand identity in competitive markets: a conceptual model". Journal of Product \& Brand Management, Vol 17 No 1, pp. 4-12. 
He, H. W. and Balmer, J. M. T. (2006). “Alliance brands: building corporate brands through strategic alliances”. Journal of Brand Management, Vol 13 No (4/5), p. 242.

Henninger, C. E., Foster, C., Alevizou, P. J. and Frohlish, C. (2016). "Stakeholder engagement in the city branding process", Place branding and public diplomacy, Vol 12 No 4, pp. 285-298.

Hoss, J., and Harradine, R. (2011). "Fashion value brands: the relationship between identity and image". Journal of Fashion Marketing and Management, Vol 15 No 3, pp. 306-325.

Instituto Nacional de Gemas e Metais Preciosos. (2015). "O setor em grandes números”. Available at $<$ http://ibgm.com.br/publicacao/o-setor-em-grandes-numeros-2015/>. Access on May 29.

Iversen, N., and Hem, L. E. (2008). "Provenance association as core values of place umbrella brands: A framework of characteristics". European Journal of Marketing, Vol 42 No (5/6), pp. 603-626.

Jack, E. P.; Raturi, A. S. (2006). "Lessons learned from methodological triangulation in management research”, Management Research News, Vol 29 No 6, pp. 345-357.

Kavaratzis, M. and Hatch, M. J. (2013). "The dynamics of place brands: an identity-based approach to place branding theory”, Marketing Theory, Vol 13 No 1, pp. 69-86.

Kilduff, K. and Núnez-Tabales, J. M. (2014). "Country image management: brand Spain in the United States (U.S.)”. Regional and Sectoral Economics Studies, Vol 14 No 2.

Lourenção, M. T. A., and Giraldi, J. M. E. (2015). "Processo de desenvolvimento e gestão de marcas setoriais: uma análise da marca Brasil Gems and Jewelry”. Revista de Administração da Unimep, Vol 13 No 3, pp. 125-153.

Lourenção, M.T.A. and Giraldi, J. M. E. (2017). "Development of an identity model for sector brands". Journal of Fashion Marketing and Management, Vol 21 No 3, pp. 317-340. 
Malhotra, N.K. (2006). Marketing Research: An Applied Orientation, Prentice Hall, Upper Saddle River, NJ.

Mindrut, S., Manolica, A., and Roman, C. T. (2015). "Building brands identity". Procedia Economics and Finance, Vol 20, p. 393-403.

Nierdele, P. A. (2011). Compromisso para a qualidade: projetos de indicação geográfica para vinhos do Brasil e na França. 2011. 236f. Tese (Doutorado em Ciências Sociais em desenvolvimento, agricultura e sociedade). Universidade Federal Rural do Rio de Janeiro.

Panigrahi, S. S. and Rao, N. S. (2018). “A stakeholders' perspective on barriers to adopt sustainable practices in MSME supply chain: issues and challenges in the textile sector", Research Journal of Textile and Apparel, Vol. 22 No 1, pp. 59-76.

Pereira, L. M. V.; Tonani, M.; Somera, S. C.; Costa, J. M. H and Pádua, S. I. D. (2016), "Application of modeling in a drug distribution and dispensing process focused on traceability in a surgical center", Knowledge and Process Management, Vol. 23 No. 2, pp. 161-168.

Riege, A. M. (2003). "Validity and reliability tests in case study research: a literature review with "hands-on" applications for each research phase", Qualitative Market Research: An International Journal, Vol. 6 No 2, pp. 75 - 86

Ringer, N. J., Giraldi, J. M. E., Capellaro, A. F., and Liboni-Amui, L. B. (2013). "The brand creation process in the information Technology Sector: The case of Brasil IT+". Internacional Journal of business administration, Vol 4 No 2, pp. 27-38.

Rojas-Méndez, J. I. The nation brand molecule. (2013). Journal of product and brand management, Vol 22 No 7, p. 462-472.

Roy, D. and Banerjee, S. (2008). "CARE-ing strategy for integration of brand identity with brand image". Internacional Journal of Commerce and Management, Vol 17 No 1, pp. 140-148. 
Roy, D. and Banerjee, S. (2014). "Identification and measurement of brand identity and image gap: a quantitative approach”. Journal of Product \& Brand Management, Vol 23 No 3, pp. 207-219.

Ruzzier, M. K., and Chernatony, L. (2013). “Developing and applying a place brand identity model: The case of Slovenia". Journal of Business Research, Vol 66 No 1, p. 45-52.

Schultz, M., Antorini, Y. M. and Csaba, F. F. (2005). “Corporate Branding: Purpose, People, Process", Copenhagen: Copenhagen Business School Press.

Silveira, C., Lages, C. and Simões, C. (2013). "Reconceptualizing brand identity in a dynamics environment", Journal of Business Research, Vol 66 No 1, p. 28-36.

Sutter, M. B.; Polo, E. F.; Maclennan and M. L. F. (2014). "Home country image attributes as source of competitive advantages: international Brazilian industry study", Review of international business, Vol 9 No 2, p. 75-93.

Tregear, A. and Gorton, M. (2009). "The challenges of sharing: brand as club goods". European Journal of Marketing, Vol 43 No 5/6, pp. 826-842.

Urde, M. (2013). “The corporate brand identity matrix". Journal of Brand management, Vol 20 No 9, p. 742-761.

Urde, M., and Greyser, S. A. (2016). "The corporate brand identity and reputation matrix - the case of Nobel prize", Journal of Brand management, Vol 23 No 1, p. 89-117.

Uzea, F. N., and Fulton, M. E. (2014). "Mechanisms for Effective Alliance Management: Insights from a Federated Cooperative Marketing System”. International Food and Agribusiness Management Review, Vol 17 No 1, p. 95-126. 
Vásquez, R, P. (2007). "Identidade de marca, gestão e comunicação". Organicom, Vol 4 No 7, pp. 201-211.

Veilleux, S. and Haskell, N.; Pons, F. (2012). Going global: how smaller enterprises

benefit from strategic alliances. Journal of Business Strategy, Vol 33 No 5, pp. 22-31.

Xie, H. Y., and Boggs, D. J. (2006). Corporate branding versus product branding in emerging markets: a conceptual framework. Marketing Intelligence \& Planning, Vol 24 No 4, pp. 347364.

Zeugner-Roth, K. P.; Zabkar, V. (2015). "Bridging the gap between country and destination image: assessing common facets and their predictive validity", Journal of Business Research, Vol 68, pp. 1844-1853. 
Figure 1 - Brasil Fashion System brand hierarchy

Brasil Fashion System

$\begin{array}{ccc}\text { Brasil by Bags } & \text { Tex Brasil Brazilian Leather Brazilian Footwear } \\ \begin{array}{c}\text { Brazil Gems and } \\ \text { Jewelry }\end{array} & \begin{array}{c}\text { Footwear Components } \\ \text { by Brasil }\end{array} \quad \text { Fashion Label Brasil }\end{array}$

Source: Lourenção and Giraldi (2017)

Table 1 - Study protocol

\begin{tabular}{|c|c|}
\hline & Study protocol \\
\hline Survey Question & $\begin{array}{l}\text { Are there similar characteristics of the sector brand identity elements among the } \\
\text { associations that compound the Brasil Fashion System brand? }\end{array}$ \\
\hline Unit of analysis & Brazilian fashion sector brand identity \\
\hline $\begin{array}{l}\text { Validity of } \\
\text { Constructs }\end{array}$ & $\begin{array}{l}\text { Comparison between theory and practice, based on the state of the art on the } \\
\text { subject }\end{array}$ \\
\hline Internal Validity & $\begin{array}{l}\text { Secondary documents } \\
\text { Interviews with managers }\end{array}$ \\
\hline Proposition & $\begin{array}{l}\text { There are characteristics of the brand identity elements that are common among } \\
\text { the associations that compound the Brasil Fashion System brand }\end{array}$ \\
\hline
\end{tabular}

Elaborated by the authors based on Pereira et al., (2016)

Table 2 - Data collected information

\begin{tabular}{llll}
\hline Association & Associated industries' products & Coding & Position Held \\
\hline ABEST & Fashion Brazilian Stylists & AS1 & $\begin{array}{l}\text { Strategic Business } \\
\text { Manager }\end{array}$ \\
\hline ABIT & Textile and clothing Brazilian industries & AS2 & $\begin{array}{l}\text { Commercial Promotion } \\
\text { Manager }\end{array}$ \\
\hline CICB & Brazilian leather companies & AS3 & Projects Manager \\
\hline ASSISNTECAL & $\begin{array}{l}\text { Brazilian Companies of Components for Leather, AS4 } \\
\text { Footwear and Manufactured Goods }\end{array}$ & Superintendent \\
\hline ABIACAV & $\begin{array}{l}\text { Brazilian industries of Bags, accessories and } \\
\text { travel items }\end{array}$ & AS5 & Projects Manager \\
\hline ABICALÇADOS & Footwear Brazilian Industries & AS6 & Projects Manager \\
\hline IBGM & Gems and Jewelry Brazilian industries & AS7 & $\begin{array}{l}\text { International } \\
\text { Coordinator }\end{array}$ \\
\hline
\end{tabular}

Source: elaborated by the authors.

Table 3 - Relation between sectorial brand elements and driving questions

\begin{tabular}{lll}
\hline Dimension & \multicolumn{1}{c}{ Elements } & \multicolumn{1}{c}{ Driving questions } \\
\hline & Personality & $\begin{array}{l}\text { What are the personality attributes of the BFS brand? Are they similar to } \\
\text { the attributes of your association's identity? }\end{array}$ \\
\hline & $\begin{array}{l}\text { Positioning } \\
\text { Product }\end{array}$ & What is the target market for your association? (Which countries?) \\
\hline
\end{tabular}




\begin{tabular}{|c|c|c|}
\hline & $\begin{array}{l}\text { Market } \\
\text { orientation }\end{array}$ & $\begin{array}{l}\text { Are the associated industries seeking to know what international } \\
\text { customers want? }\end{array}$ \\
\hline \multirow{4}{*}{ 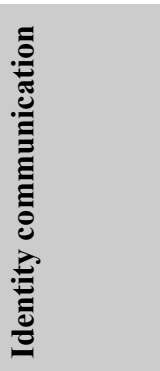 } & $\begin{array}{l}\text { Marketing } \\
\text { campaign }\end{array}$ & $\begin{array}{l}\text { How is the marketing campaign abroad? } \\
\text { Do all associations participate? Who defines how the campaign will be } \\
\text { and its attributes? }\end{array}$ \\
\hline & Visual identity & $\begin{array}{l}\text { What would be important to be communicated by the visual identity to } \\
\text { your association? }\end{array}$ \\
\hline & Stationary & $\begin{array}{l}\text { Was stationery developed for Brasil Fashion System? Is it used by your } \\
\text { association? }\end{array}$ \\
\hline & $\begin{array}{l}\text { Promotion } \\
\text { Tools }\end{array}$ & $\begin{array}{l}\text { What are the promotional tools that your association uses to promote the } \\
\text { BFS brand? }\end{array}$ \\
\hline \multirow{2}{*}{ 党: } & Relationship & $\begin{array}{l}\text { Are there relationship programs of your association's industries with } \\
\text { international clients? }\end{array}$ \\
\hline & $\begin{array}{l}\text { Product } \\
\text { Performance }\end{array}$ & $\begin{array}{l}\text { Do you seek to know if your products are being accepted by international } \\
\text { buyers? }\end{array}$ \\
\hline \multirow{3}{*}{ 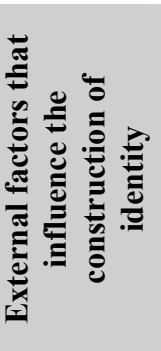 } & $\begin{array}{l}\text { Competitor' } \\
\text { actions }\end{array}$ & Which countries are the main competitors for your association? \\
\hline & Environment & $\begin{array}{l}\text { For your association, to export products with a brand that links it to } \\
\text { Brazilian characteristics, is it something positive or negative? Is there } \\
\text { prejudice with Brazilian products? }\end{array}$ \\
\hline & $\begin{array}{l}\text { Consumer } \\
\text { Attitudes and } \\
\text { Behavior }\end{array}$ & $\begin{array}{l}\text { Do you have knowledge about the buyer's behavior in the market that the } \\
\text { products will be exported? } \\
\text { Have any international buyers demonstrated restrictions on Brazilian } \\
\text { products? }\end{array}$ \\
\hline
\end{tabular}

Source: elaborated by the authors.

Figure 2: Flowchart of the Research methodology

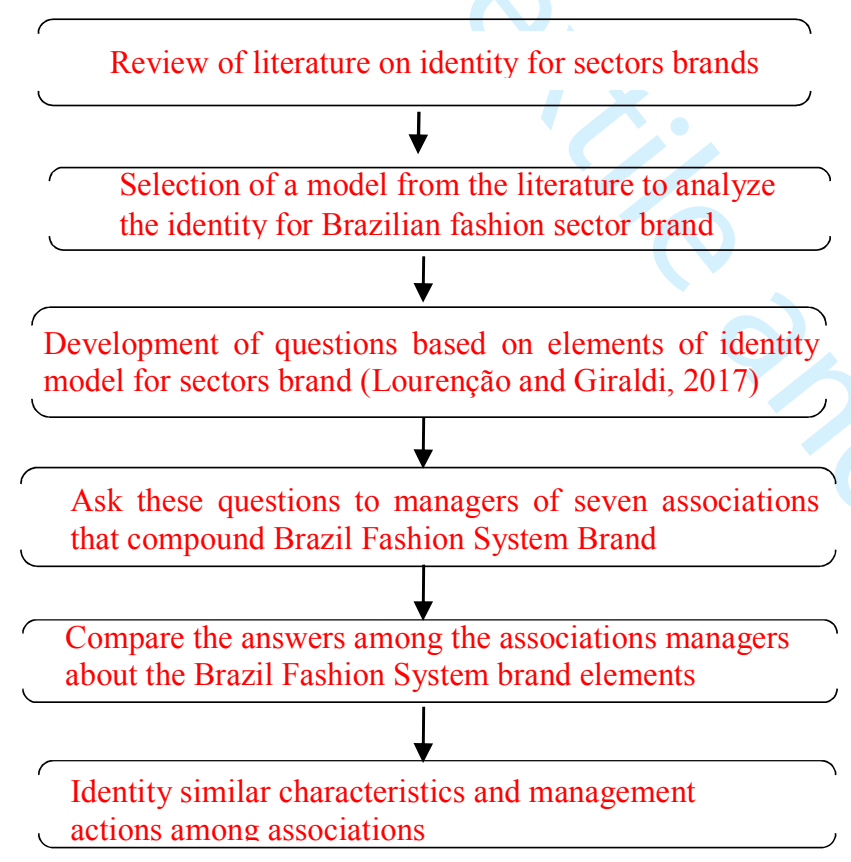


Table 4 - Similar and distinct attributes among associations of the Brazilian fashion sector

\begin{tabular}{|c|c|c|c|c|c|c|c|}
\hline $\begin{array}{l}\text { Association/ } \\
\text { Elements }\end{array}$ & AS1 & AS2 & AS3 & AS4 & AS5 & AS6 & AS7 \\
\hline \multicolumn{8}{|c|}{ DIMENSION I: COMPONENTS OF IDENTITY } \\
\hline Personality & $\begin{array}{l}\text { - Tex Brasil } \\
\text { personality } \\
\text { attributes: } \\
\text { creativity; } \\
\text { innovation; } \\
\text { tecnology; } \\
\text { diversity; } \\
\text { sustainable; } \\
\text { quality; vibrant; } \\
\text { authentic; } \\
\text { design }\end{array}$ & $\begin{array}{l}\text { - Fashion } \\
\text { Label brand } \\
\text { personality: } \\
\text { - Innovation; } \\
\text { contemporary }\end{array}$ & $\begin{array}{l}\text { - Brazillian } \\
\text { Leather: } \\
\text { Sustainable } \\
\text {; Design; } \\
\text { Innovation }\end{array}$ & $\begin{array}{l}\text {-By Brazil } \\
\text { components } \\
\text { and chemicals } \\
\text { brand } \\
\text { personality: } \\
\text { Originality; } \\
\text { Diversity; } \\
\text { Technology; } \\
\text { Fashion }\end{array}$ & $\begin{array}{l}\text { - Bags by Brazil } \\
\text { brand } \\
\text { personality: } \\
\text { Fashion; } \\
\text { Criativity; } \\
\text { Quality; } \\
\text { Innovation; } \\
\text { Contemporary }\end{array}$ & $\begin{array}{l}\text { - Brazilian } \\
\text { footwear } \\
\text { brand } \\
\text { personality: } \\
\text { credibility; } \\
\text { assurance; } \\
\text { trust; agility; } \\
\text { business }\end{array}$ & $\begin{array}{l}\text { - Brazil gems } \\
\text { and Jewelry } \\
\text { brand } \\
\text { personality: } \\
\text { design; } \\
\text { diversity }\end{array}$ \\
\hline Positioning & $\begin{array}{l}\text { Germany, USA; } \\
\text { France; Hong } \\
\text { Kong; Unit } \\
\text { Kingdom; } \\
\text { Portugal; Japan }\end{array}$ & $\begin{array}{l}\text { USA; France; } \\
\text { Colombia, Unit } \\
\text { Kingdom; } \\
\text { China, } \\
\text { Argentina; } \\
\text { Middle East }\end{array}$ & $\begin{array}{l}\text { Hong Kong; } \\
\text { China; } \\
\text { France; Italy, } \\
\text { Vietnam }\end{array}$ & $\begin{array}{l}\text { Hong Kong; } \\
\text { USA } \\
\text { Colombia; } \\
\text { Peru; } \\
\text { Argentina; }\end{array}$ & $\begin{array}{l}\text { USA; France; } \\
\text { Colombia; } \\
\text { Russia; Chile. }\end{array}$ & $\begin{array}{l}\text { USA; } \\
\text { Colombia; } \\
\text { Hong Kong; } \\
\text { Russia; } \\
\text { Germany; } \\
\text { United Arab } \\
\text { Emirates } \\
\end{array}$ & $\begin{array}{l}\text { USA; Hong } \\
\text { Kong; } \\
\text { Colombia; } \\
\text { Germany; } \\
\text { Switzerland }\end{array}$ \\
\hline Product & $\begin{array}{l}\text { Freshness; } \\
\text { Diversity; } \\
\text { Relationship }\end{array}$ & $\begin{array}{c}\text { Not } \\
\text { determined }\end{array}$ & $\begin{array}{l}\text { Leather for } \\
\text { furniture }\end{array}$ & $\begin{array}{c}\text { News; } \\
\text { Originality }\end{array}$ & $\begin{array}{l}\text { Quality; Good } \\
\text { workmanship }\end{array}$ & $\begin{array}{l}\text { Quality; } \\
\text { Design }\end{array}$ & $\begin{array}{l}\text { Design; } \\
\text { Diversity; } \\
\text { Versatile; } \\
\text { Handcrafted }\end{array}$ \\
\hline $\begin{array}{l}\text { Country of } \\
\text { origin }\end{array}$ & $\begin{array}{l}\text { Products of this } \\
\text { industries } \\
\text { association are } \\
\text { linked to the } \\
\text { country of origin } \\
\text { characteristics }\end{array}$ & $\begin{array}{l}\text { Products of } \\
\text { this industries } \\
\text { association are } \\
\text { linked to the } \\
\text { country of } \\
\text { origin } \\
\text { characteristics }\end{array}$ & $\begin{array}{l}\text { Products of } \\
\text { this } \\
\text { industries } \\
\text { association } \\
\text { are linked to } \\
\text { the country } \\
\text { of origin } \\
\text { characteristic } \\
\text { s } \\
\end{array}$ & $\begin{array}{l}\text { Products of } \\
\text { this industries } \\
\text { association are } \\
\text { linked to the } \\
\text { country of } \\
\text { origin } \\
\text { characteristics }\end{array}$ & $\begin{array}{l}\text { Products of this } \\
\text { industries } \\
\text { association are } \\
\text { not linked to the } \\
\text { country of origin } \\
\text { characteristics }\end{array}$ & $\begin{array}{l}\text { Products of } \\
\text { this industries } \\
\text { association are } \\
\text { not linked to } \\
\text { the country of } \\
\text { origin } \\
\text { characteristics }\end{array}$ & $\begin{array}{l}\text { Products of } \\
\text { this industries } \\
\text { association are } \\
\text { linked to the } \\
\text { country of } \\
\text { origin } \\
\text { characteristics }\end{array}$ \\
\hline $\begin{array}{l}\text { Market } \\
\text { orientation }\end{array}$ & $\begin{array}{l}\text { This association } \\
\text { analysis the } \\
\text { foreign market so } \\
\text { the industries can } \\
\text { export products } \\
\text { adapted to them }\end{array}$ & $\begin{array}{l}\text { This } \\
\text { association } \\
\text { analysis the } \\
\text { foreign market } \\
\text { so the } \\
\text { industries can } \\
\text { export } \\
\text { products } \\
\text { adapted to } \\
\text { them }\end{array}$ & $\begin{array}{l}\text { This } \\
\text { association } \\
\text { analysis the } \\
\text { foreign } \\
\text { market so } \\
\text { the } \\
\text { industries } \\
\text { can export } \\
\text { products } \\
\text { adapted to } \\
\text { them }\end{array}$ & $\begin{array}{l}\text { This } \\
\text { association } \\
\text { analysis the } \\
\text { foreign market } \\
\text { so the } \\
\text { industries can } \\
\text { export } \\
\text { products } \\
\text { adapted to } \\
\text { them }\end{array}$ & $\begin{array}{l}\text { This association } \\
\text { analysis the } \\
\text { foreign market so } \\
\text { the industries can } \\
\text { export products } \\
\text { adapted to them }\end{array}$ & $\begin{array}{l}\text { This } \\
\text { association } \\
\text { analysis the } \\
\text { foreign market } \\
\text { so the } \\
\text { industries can } \\
\text { export } \\
\text { products } \\
\text { adapted to } \\
\text { them }\end{array}$ & $\begin{array}{l}\text { This } \\
\text { association } \\
\text { analysis the } \\
\text { foreign market } \\
\text { so the } \\
\text { industries can } \\
\text { export } \\
\text { products } \\
\text { adapted to } \\
\text { them }\end{array}$ \\
\hline \multicolumn{8}{|c|}{ DIMENSION II: COMMUNICATION COMPONENTS } \\
\hline $\begin{array}{l}\text { Marketing } \\
\text { Campaign }\end{array}$ & $\begin{array}{l}\text { - Brand is used } \\
\text { with two or more } \\
\text { associations; } \\
\text { - Meetings are } \\
\text { made when the } \\
\text { brand is going to } \\
\text { be used }\end{array}$ & $\begin{array}{l}\text { - Brand is used } \\
\text { with two or } \\
\text { more } \\
\text { associations; } \\
\text { - Meetings are } \\
\text { made when the } \\
\text { brand is going } \\
\text { to be used }\end{array}$ & $\begin{array}{l}\text { the brand is } \\
\text { not being } \\
\text { used at the } \\
\text { moment }\end{array}$ & $\begin{array}{l}\text { - Brand is used } \\
\text { with two or } \\
\text { more } \\
\text { associations; } \\
\text { - Meetings are } \\
\text { made when the } \\
\text { brand is going } \\
\text { to be used }\end{array}$ & $\begin{array}{l}\text { - Brand is used } \\
\text { with two or more } \\
\text { associations; } \\
\text { - Meetings are } \\
\text { made when the } \\
\text { brand is going to } \\
\text { be used }\end{array}$ & $\begin{array}{l}\text { the brand is not } \\
\text { being used at } \\
\text { the moment }\end{array}$ & $\begin{array}{l}\text { - Brand is used } \\
\text { with two or } \\
\text { more } \\
\text { associations; } \\
\text { - Meetings are } \\
\text { made when the } \\
\text { brand is going } \\
\text { to be used } \\
\text {-Already used } \\
\text { the brand } \\
\text { without being } \\
\text { in a collective } \\
\text { event }\end{array}$ \\
\hline $\begin{array}{l}\text { Visual } \\
\text { identity }\end{array}$ & $\begin{array}{l}\text { Quality; } \\
\text { Contemporaneou } \\
\text { s }\end{array}$ & $\begin{array}{l}\text { Taglines } \\
\text { suitable for } \\
\text { some events }\end{array}$ & $\begin{array}{l}\text { Added } \\
\text { Value; } \\
\text { Contempora } \\
\text { neous }\end{array}$ & $\begin{array}{l}\text { Quality; } \\
\text { Agility }\end{array}$ & Quality & $\begin{array}{l}\text { Quality; Know } \\
\text { how in } \\
\text { exportation; } \\
\text { Diversity of } \\
\text { colors in } \\
\text { materials } \\
\end{array}$ & $\begin{array}{l}\text { Exclusivity; } \\
\text { Handcraft }\end{array}$ \\
\hline Stationary & Never developed & $\begin{array}{l}\text { Never } \\
\text { developed }\end{array}$ & $\begin{array}{l}\text { Never } \\
\text { developed }\end{array}$ & $\begin{array}{l}\text { Never } \\
\text { developed }\end{array}$ & $\begin{array}{l}\text { Develops for } \\
\text { promotional } \\
\text { actions abroad }\end{array}$ & $\begin{array}{l}\text { Never } \\
\text { developed }\end{array}$ & $\begin{array}{l}\text { Never } \\
\text { developed }\end{array}$ \\
\hline
\end{tabular}




\begin{tabular}{|c|c|c|c|c|c|c|c|}
\hline $\begin{array}{l}\text { Promotion } \\
\text { Tools }\end{array}$ & $\begin{array}{l}\text { Stand; Site and } \\
\text { flyers }\end{array}$ & $\begin{array}{l}\text { Stand; Site and } \\
\text { flyers }\end{array}$ & Site & $\begin{array}{l}\text { Various } \\
\text { communication } \\
\text { vehicles }\end{array}$ & Stands & $\begin{array}{l}\text { The brand is } \\
\text { not being } \\
\text { promoted; the } \\
\text { development } \\
\text { of an e- } \\
\text { commerce for } \\
\text { the brand is } \\
\text { suggested }\end{array}$ & $\begin{array}{l}\text { Stand; Site and } \\
\text { flyers }\end{array}$ \\
\hline $\begin{array}{l}\text { Relationship } \\
\text { with buyers }\end{array}$ & $\begin{array}{l}\text { The association } \\
\text { seek to encourage } \\
\text { the relationship } \\
\text { with international } \\
\text { buyer }\end{array}$ & $\begin{array}{l}\text { The } \\
\text { association } \\
\text { seek to } \\
\text { encourage the } \\
\text { relationship } \\
\text { with } \\
\text { international } \\
\text { buyer }\end{array}$ & $\begin{array}{l}\text { The } \\
\text { association } \\
\text { seek to } \\
\text { encourage } \\
\text { the } \\
\text { relationship } \\
\text { with } \\
\text { international } \\
\text { buyer } \\
\end{array}$ & $\begin{array}{l}\text { The } \\
\text { association } \\
\text { seek to } \\
\text { encourage the } \\
\text { relationship } \\
\text { with } \\
\text { international } \\
\text { buyer }\end{array}$ & $\begin{array}{l}\text { The association } \\
\text { seek to } \\
\text { encourage the } \\
\text { relationship with } \\
\text { international } \\
\text { buyer }\end{array}$ & \begin{tabular}{|l} 
The \\
association \\
seek to \\
encourage the \\
relationship \\
with \\
international \\
buyer
\end{tabular} & $\begin{array}{l}\text { The } \\
\text { association } \\
\text { seek to } \\
\text { encourage the } \\
\text { relationship } \\
\text { with } \\
\text { international } \\
\text { buyer }\end{array}$ \\
\hline $\begin{array}{l}\text { Product } \\
\text { performance }\end{array}$ & $\begin{array}{l}\text { Performance } \\
\text { verified by } \\
\text { statistical data }\end{array}$ & $\begin{array}{l}\text { Performance } \\
\text { verified by } \\
\text { statistical data }\end{array}$ & $\begin{array}{l}\text { Performance } \\
\text { verified by } \\
\text { statistical } \\
\text { data }\end{array}$ & $\begin{array}{l}\text { Performance } \\
\text { verified by } \\
\text { statistical data }\end{array}$ & $\begin{array}{l}\text { Performance } \\
\text { verified by } \\
\text { statistical data }\end{array}$ & $\begin{array}{l}\text { Performance } \\
\text { verified by } \\
\text { statistical data }\end{array}$ & $\begin{array}{l}\text { Performance } \\
\text { verified by } \\
\text { statistical data } \\
\text { and also by } \\
\text { informal } \\
\text { conversations } \\
\text { with } \\
\text { entrepreneur } \\
\end{array}$ \\
\hline \multicolumn{8}{|c|}{ DIMENSION IV: EXTERNAL FACTORS THAT INFLUENCE BRAND IDENTITY } \\
\hline $\begin{array}{l}\text { Competitors } \\
\text { actions }\end{array}$ & Italy; France & $\begin{array}{l}\text { Colombia; } \\
\text { Peru; India; } \\
\text { Bangladesh; } \\
\text { China } \\
\end{array}$ & China & $\begin{array}{l}\text { Italy; Spain; } \\
\text { Germany }\end{array}$ & $\begin{array}{l}\text { Italy; China; } \\
\text { Colombia }\end{array}$ & $\begin{array}{l}\text { Italy; Portugal; } \\
\text { China }\end{array}$ & $\begin{array}{l}\text { Asia; China; } \\
\text { Italy. }\end{array}$ \\
\hline $\begin{array}{l}\text { Environment } \\
\text { al conditions }\end{array}$ & $\begin{array}{l}\text { Positive } \\
\text { perceptions }\end{array}$ & \begin{tabular}{|l} 
Perception of \\
Brazilian \\
image various \\
between \\
countries \\
\end{tabular} & $\begin{array}{l}\text { Improvemen } \\
\mathrm{t} \text { in the } \\
\text { Brazilian } \\
\text { image }\end{array}$ & $\begin{array}{l}\text { Improvement } \\
\text { in the Brazilian } \\
\text { image }\end{array}$ & \begin{tabular}{|l|} 
Brazilian \\
economic crisis \\
is seen as \\
temporary by the \\
foreign buyers \\
\end{tabular} & \begin{tabular}{|l} 
Perception of \\
Brazilian \\
image various \\
between \\
countries \\
\end{tabular} & $\begin{array}{l}\text { Positive } \\
\text { perceptions }\end{array}$ \\
\hline $\begin{array}{l}\text { Buyer's } \\
\text { Attitudes } \\
\text { and } \\
\text { Behavior }\end{array}$ & $\begin{array}{l}\text { - Evaluate buyer } \\
\text { behavior before } \\
\text { going to market } \\
\text { - Post purchase } \\
\text { evaluation: no } \\
\text { prejudice has } \\
\text { ever occurred } \\
\text { with Brazilian } \\
\text { product }\end{array}$ & $\begin{array}{l}\text { - Evaluate } \\
\text { buyer } \\
\text { behavior } \\
\text { before going } \\
\text { to market } \\
\text { - Post } \\
\text { purchase } \\
\text { evaluation: } \\
\text { delay in } \\
\text { product } \\
\text { delivery }\end{array}$ & $\begin{array}{l}\text { - Evaluate } \\
\text { buyer } \\
\text { behavior } \\
\text { before } \\
\text { going to } \\
\text { market }\end{array}$ & $\begin{array}{l}\text { - Evaluate } \\
\text { buyer } \\
\text { behavior } \\
\text { before going } \\
\text { to market } \\
\text { - Post } \\
\text { purchase } \\
\text { evaluation: } \\
\text { some foreign } \\
\text { buyers } \\
\text { saying that } \\
\text { Brazilian } \\
\text { exportation } \\
\text { occurs just } \\
\text { because the } \\
\text { high dollar } \\
\end{array}$ & $\begin{array}{l}\text { - Evaluate buyer } \\
\text { behavior before } \\
\text { going to market } \\
\text { - Post purchase } \\
\text { evaluation: no } \\
\text { prejudice has } \\
\text { ever occurred } \\
\text { with Brazilian } \\
\text { product }\end{array}$ & \begin{tabular}{|l} 
- Evaluate \\
buyer \\
behavior \\
before going \\
to market \\
- Post \\
purchase \\
evaluation: \\
difficult to \\
communicate \\
value added \\
of the \\
Brazilian \\
products
\end{tabular} & $\begin{array}{l}\text { - Evaluate } \\
\text { buyer } \\
\text { behavior } \\
\text { before going } \\
\text { to market } \\
\text { - Post } \\
\text { purchase } \\
\text { evaluation: } \\
\text { delay in } \\
\text { product } \\
\text { delivery }\end{array}$ \\
\hline
\end{tabular}

Source: authors' elaboration 
Figure 3 - Current and ideal situation of the identity and image of Brasil Fashion System

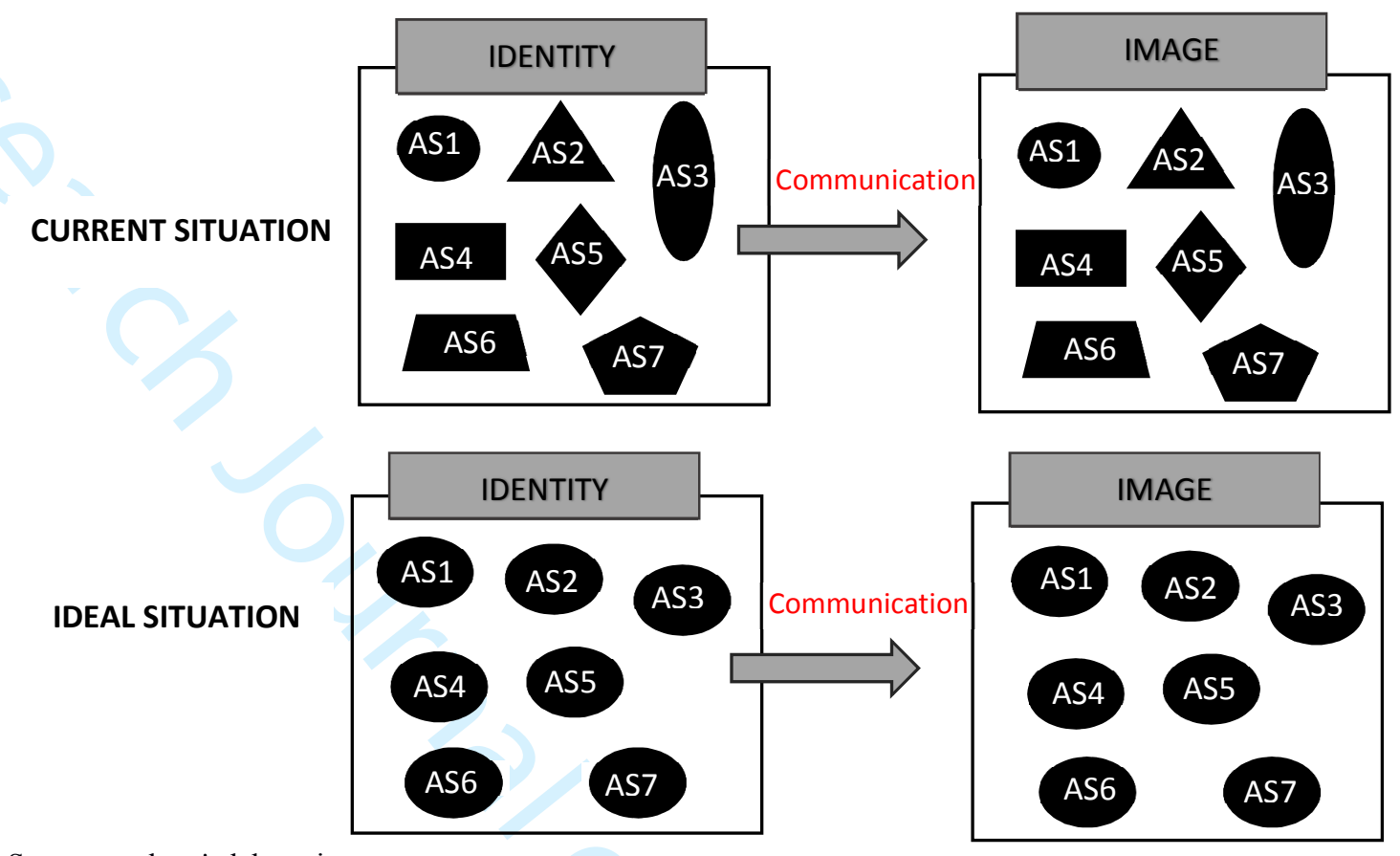

Source: authors' elaboration 

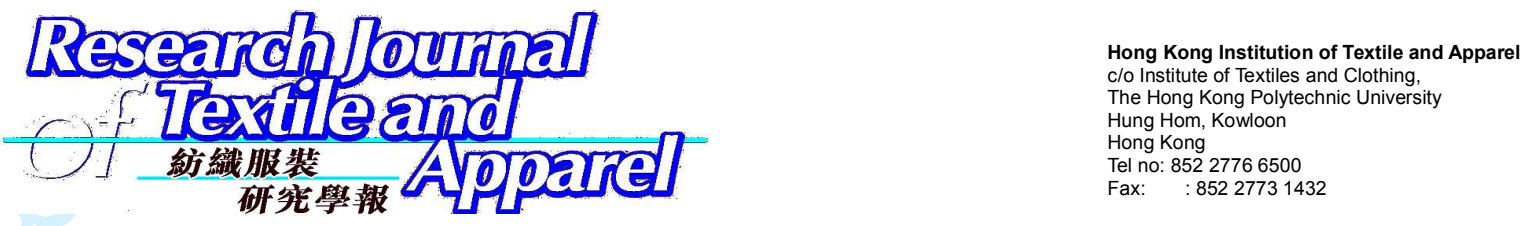

\section{AMENDMENT FORM FOR MANUSCRIPT}

Please complete this amendment form and attached together in your submission.

\begin{tabular}{|l|l|}
\hline Submission Date (13/03/2018): & Manuscript ID: RJTA- 12-2017-0055 \\
\hline$\square 1^{\text {st }}$ Revised & \\
\hline$\square 2^{\text {nd }}$ Revised & \\
$\square 3^{\text {rd }}$ Revised / Final Revised &
\end{tabular}

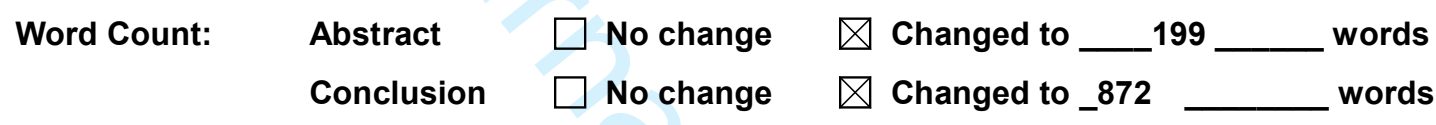

\begin{tabular}{|c|c|}
\hline Heading / Paragraph / Section & Changes (Please specify) \\
\hline Introduction/ $8^{\text {th }}$ paragraph & $\begin{array}{l}\text { Correction in the objective: the objective of this study is to identify similar } \\
\text { characteristics and managerial actions of the sector brand identity elements among } \\
\text { the associations that compound the Brasil Fashion System brand. }\end{array}$ \\
\hline Introduction $/ 10^{\text {th }}$ paragraph & $\begin{array}{l}\text { A better explanation was added into lines } 71-76 \text {, to indicate what is missing in the } \\
\text { literature and what the present study is looking for. }\end{array}$ \\
\hline Sectorial Brands/ $2^{\text {nd }}$ paragraph & $\begin{array}{l}\text { (Lines 151-154): It has been added the information that Brazil is one of the } \\
\text { countries with the greatest variety of gemstones. This information was taken from a } \\
\text { sectoral data report of the Brazilian gem and precious metals institute. } \\
\text { Also, was added the information that the gem and precious metals sector has an } \\
\text { image consistent with some attributes of the image of Brazil abroad, such as } \\
\text { diversity, colors and fun. This information had the theoretical basis of the study by } \\
\text { Sutter et al., 2014. }\end{array}$ \\
\hline $\begin{array}{l}\text { Methodology/Research Methods/ } \\
2^{\text {nd }} \text { paragraph }\end{array}$ & A study protocol was added (Table 1) \\
\hline $\begin{array}{l}\text { Methodology/Data collected } / 2^{\text {nd }} \\
\text { paragraph }\end{array}$ & $\begin{array}{l}\text { Table } 2 \text { was added. Table } 2 \text { provide information on: i) products commercialized by } \\
\text { industries associated, ii) codification; and iii) each position held by interviewers. }\end{array}$ \\
\hline $\begin{array}{l}\text { Methodology/Data analysis/ } 1^{\text {st }} \\
2^{\text {nd }}, 3^{\text {rd }} \text { and } 4 \text { th paragraphs }\end{array}$ & $\begin{array}{l}\text { More details about data analysis was added and a flowchart of the research } \\
\text { methodology is proposed based on the study of Panigrahi and Rao (2018) - ( Figure } \\
\text { 2) }\end{array}$ \\
\hline
\end{tabular}



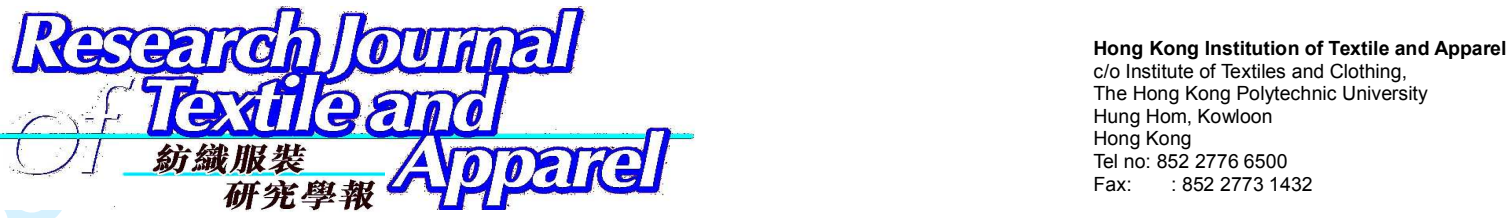

\begin{tabular}{|c|c|}
\hline Results/ $1^{\text {st }}$ paragraph & $\begin{array}{l}\text { Most common sectoral brand identity elements and managerial actions among the } \\
\text { associations were highlighted. }\end{array}$ \\
\hline Results/ $2^{\text {nd }}$ paragraph & Explanation on brand identity related to the results was added. \\
\hline Results/ $2^{\text {nd }}$ paragraph & $\begin{array}{l}\text { Another change was dividing the "results" section into subitems to be clearer. It was } \\
\text { divided into four subitems that represent the four dimensions analyzed in the } \\
\text { present study based on the sector brand identity management model of Lourenção } \\
\text { and Giraldi (2017). The four sub-items are the same that also divide Table } 2 \text {. In this } \\
\text { way it is easier to follow the explanation of the results relating them to Table } 2 \text {. }\end{array}$ \\
\hline $\begin{array}{l}\text { Results/ Results for identity } \\
\text { components/ } 1^{\text {st }} \text { paragraph }\end{array}$ & $\begin{array}{l}\text { It was added an explanation about the dimension called identity component and its } \\
\text { elements. }\end{array}$ \\
\hline $\begin{array}{l}\text { Results/ Results for identity } \\
\text { components/ } 2^{\text {st }} \text { paragraph }\end{array}$ & $\begin{array}{l}\text { The characteristics and common managerial actions among the majority of the } \\
\text { associations found in the interviews with their managers were added in this } \\
\text { paragraph (about the dimension called "Identity components") }\end{array}$ \\
\hline $\begin{array}{l}\text { Results/ results for identity } \\
\text { components } / 4^{\text {th }}, 5^{\text {th }}, 6^{\text {th }}, 7^{\text {th }} \\
\text { paragraphs }\end{array}$ & Relevance for each element of the dimension "identity components" was added. \\
\hline $\begin{array}{l}\text { Results/ results for communication } \\
\text { components/ } 2^{\text {nd }} \text { paragraph }\end{array}$ & An explanation on which are the communication components was added. \\
\hline $\begin{array}{l}\text { Results/ results for communication } \\
\text { components } / 3^{\text {rd }} \text { paragraph }\end{array}$ & More details about selection of attributes for BFS brand visual identity was added. \\
\hline $\begin{array}{l}\text { Results/ results for brand identity } \\
\text { delivery elements } / 2^{\text {nd }} \text { paragraph }\end{array}$ & An example about relationship with international buyers was added. \\
\hline $\begin{array}{l}\text { Results/ results for brand identity } \\
\text { delivery elements } / 3^{\text {rd }} \text { paragraph }\end{array}$ & $\begin{array}{l}\text { An example about product performance observation through informal conversation } \\
\text { was added. }\end{array}$ \\
\hline Discussion -1 th paragraph & It was indicated general discussions about management of sector brand identity. \\
\hline Discussion $-2^{\text {nd }}$ paragraph & Proposition confirmation. \\
\hline
\end{tabular}



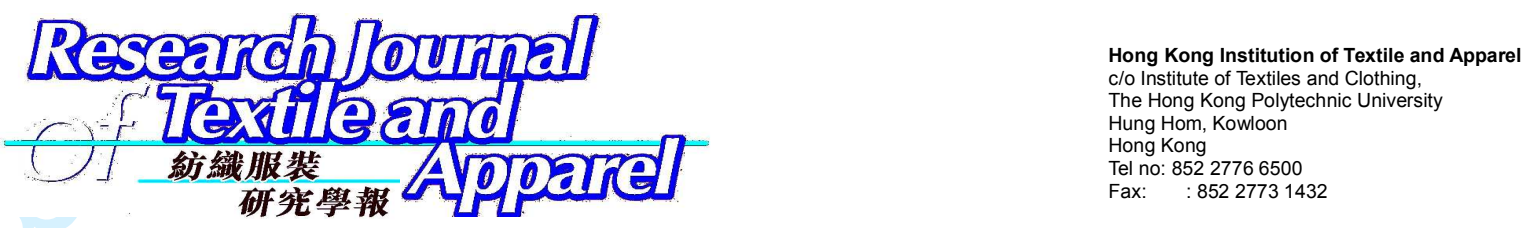

\begin{tabular}{|c|c|}
\hline Discussion $-3^{\text {rd }}$ paragraph & $\begin{array}{l}\text { It indicates that besides the proposition confirmation there are several } \\
\text { characteristics and managerial actions on BFS brand identity that are not similar } \\
\text { between the partners. }\end{array}$ \\
\hline Discussion $-7^{\text {th }}$ paragraph & A theoretical reference was added to support the construction of the Figure 3. \\
\hline Discussion $-8^{\text {th }}$ paragraph & $\begin{array}{l}\text { A question is opened and it is suggested a response, indicating that perhaps the } \\
\text { BFS brand should not be used by some of its partners. Theoretical background } \\
\text { was added for this discussion (Castro \& Giraldi, 2015; Lourenção \& Giraldi, } \\
\text { 2017; Dinnie, 2017). }\end{array}$ \\
\hline Conclusion $-1^{\text {st }}$ paragraph & $\begin{array}{l}\text { A theory about the management of sectorial brand identity is added just to } \\
\text { introduce the conclusion. }\end{array}$ \\
\hline Conclusion $-2^{\text {st }}$ paragraph & $\begin{array}{l}\text { The conclusions were presented in topics to make them more visible and clear. For } \\
\text { each conclusion a theoretical foundation was indicated. }\end{array}$ \\
\hline Conclusion $-3^{\text {rd }}$ and $4^{\text {th }}$ paragraph & $\begin{array}{l}\text { Theoretical and practical contributions were also improved based on the } \\
\text { modifications made. }\end{array}$ \\
\hline
\end{tabular}

Remarks:

*Please tick whichever not applicable 


\section{Semi structured interview questions}

1. What are the personality attributes of the BFS brand? Are they similar to the attributes of your association's identity?

2. What is the target market for your association? (Which countries?)

3. By what characteristics are your products known abroad?

4. Does the Brasil Fashion System brand have an association with Brazil?

5. Are the associated industries seeking to know what international customers want?

6. How is the marketing campaign abroad?

7. Do all associations participate? Who defines how the campaign will be and its attributes?

8. What would be important to be communicated by the visual identity to your association?

9. Was stationery developed for Brasil Fashion System? Is it used by your association?

10. What are the promotional tools that your association uses to promote the BFS brand?

11. Are there relationship programs of your association's industries with international clients?

12. Are there relationship programs of your association's industries with international buyers?

13. Which countries are the main competitors for your association?

14. For your association, to export products with a brand that links it to Brazilian characteristics, is it something positive or negative? Is there prejudice with Brazilian products?

15. Do you have knowledge about the buyer's behavior in the market that the products will be exported?

16. Have any international buyers demonstrated restrictions on Brazilian products? 